\title{
Aid for Trade and the Quality of Exports
}

\author{
Zheng Wang ${ }^{a, b, *}$, Meina $\mathrm{Xu}^{c}$ \\ ${ }^{a}$ Leicester Business School, De Montfort University, Leicester, LE1 9BH, United \\ Kingdom. Phone: +44 0116257 4880. Email: zheng.wang@dmu.ac.uk \\ ${ }^{b}$ GEP, University of Nottingham, Nottingham, United Kingdom \\ ${ }^{c}$ Institute of International Business, Shanghai University of International Busi- \\ ness and Economics, Shanghai, China. Email: xumeinax@suibe.edu.cn
}

Revised version: July 5, 2017

\begin{abstract}
This paper studies how aid for trade (AfT) affects the quality of recipient countries' exports. It shows that the quality effect is most discernible for AfT for assistance in trade policy: a $50 \%$ increase in the value of AfT received in this category is associated with a $0.5 \%-1 \%$ increase in the quality of exports to the donor and other OECD countries. On average, the actual AfT received for assistance in trade policy leads to a $2 \%$ upgrade of the recipient country in the quality ladder of all developing countries. Around half of this quality effect is driven by the quality improvement of continued products in continued markets (intensive margin), and the other half by the quality upgrading of new products in continued markets and existing products in new markets (extensive margin).
\end{abstract}

Key Words: Aid for Trade; Exports; Quality; Quality ladder JEL Codes: F35, L15, O19, O24

Running Title: Aid for Trade and the Quality of Exports Acknowledgement: This work was supported by the the National Science Foundation of China under Grant No. 71373156.

\footnotetext{
${ }^{*}$ Corresponding author.
} 


\section{Aid for Trade and the Quality of Exports}

\section{Introduction}

Despite the pivotal role of aid for trade (AfT) in international development assistance, its impact is only recently assessed with a focus on its effectiveness in promoting the trade value of the recipients (Calí and te Velde, 2011; Helble et al., 2012; Pettersson and Johansson, 2013; Vijil and Wagner, 2012). This paper investigates the effects of AfT on trade from a new angle: we study whether and how AfT affects the quality of the recipient countries' exports and hence their positions in the global quality ladder.

The contribution of this research is twofold. First, our research adds a new aspect - i.e. the quality of exports - to the recent AfT effectiveness evaluation literature where AfT is shown to have some positive but limited impact on trade value (Calí and te Velde, 2011; Helble et al., 2012; Pettersson and Johansson, 2013; Vijil and Wagner, 2012). ${ }^{1}$ While AfT funds target specifically at the building of the recipient countries' supply-side capacity for deeper integration into the world economy (OECD/WTO, 2007), the expansion of global value chains presents a new concern for the effectiveness of AfT: in response to the increasing fragmentation of production across borders, AfT is now being geared toward the needs for enhancing an aided country's comparative advantage in the value chain through the provision of products and services at internationally competitive cost and quality (Lammersen and Roberts, 2015; OECD/WTO, 2013). Following this rationale, we first provide an assessment of the impact of AfT on the quality of the recipients' exports, distinguishing the effects from AfT of different categories as well as the effects for different export markets. Second, we examine the time pattern of the quality effects of AfT and look into the intensive and extensive margins along the market and product dimensions. A close look at the market and product dynamics gives useful information about the sources of the effects observed, offering a more accurate anatomy and deeper

\footnotetext{
${ }^{1}$ Using non-stationary panel estimators, Nowak-Lehmann et al. (2013) find negative but insignificant impact of general aid (official development assistance which includes AfT) on recipients' exports to donors.
} 
understanding of the workings of AfT in recipient countries.

\section{Methodology and Data}

A widely used proxy for product quality is product price (or unit value). The main problem with price as a measure of quality is that it reflects not only quality but also the markup and productivity of firms. To isolate the "true" quality component from product prices, we adopt an estimation approach for differentiated products used widely in the empirical IO literature (e.g. Anderson et al., 1988, 1992). Specifically, we estimate the following structurally derived equation as in Khandelwal (2010) and Khandelwal et al. (2013):

$$
\ln q_{i j k t}+\sigma_{k} \ln p_{i j k t}=\omega_{j t}+\omega_{k}+\epsilon_{i j k t}
$$

where $q_{i j k t}$ is the quantity of product $k$ exported by country $i$ to country $j$ in year $t$; $p_{i j k t}$ is the price and $\sigma_{k}$ is the elasticity of substitution of the product; the fixed effect $\omega_{j t}$ controls for all market-year-specific characteristics such as income and general price index; and the fixed effect $\omega_{k}$ is introduced to control for all product-specific factors such as the unit of measurement (e.g. kg, tonne, meter), ensuring the comparability of quantities and prices across products. The inferred quality can then be recovered from the residual of the regression as $\hat{\lambda}_{i j k t}=\hat{\epsilon}_{i j k t} /\left(\sigma_{k}-1\right)$. An institutional explanation of this estimate of quality is as follows. When product prices are the same, consumers would prefer and buy a larger quantity of higher-quality products. A bigger $\epsilon$ means a higher quantity of sales $q$ when product prices $p$ are controlled for, hence reflecting a higher quality $\lambda$ of the product. To facilitate the following country-country-year-level analysis, we further construct $\hat{\lambda}_{i j t}$ as a weight average of $\hat{\lambda}_{i j k t}$ with the weight being the share of each product in the export value. ${ }^{2}$

\footnotetext{
${ }^{2}$ There are three problems with country-country-product-year-level regressions. First, because of the inter-sectoral nature of a great part of AfT (e.g. technical assistance on trade policy) even the most disaggregated AfT statistics cannot be cleanly aligned with products or industries. Second, such disaggregated level regressions are computationally very demanding especially with high-dimensional fixed effects. Third, results of regressions at this level may be driven by the bias from the fact that some observations are assigned a large weight in the sample simply because some countries happen to export
} 
The effect of AfT on the quality of exports is estimated from regressions that take the following form:

$$
\hat{\lambda}_{i j t}=\alpha+\sum_{m} \beta^{m} A f T_{i j, t-s \text { to } t-1}^{m}+\sum_{m} \theta^{m} O A f T_{i j, t-s \text { to } t-1}^{m}+\mathbf{X} \boldsymbol{\Gamma}_{i j t}+\delta_{i t}+\mu_{j t}+\nu_{i j t},
$$

where $A f T_{i j, t-s \text { to } t}^{m}$ is the $\log$ value of AfT from donor $j$ to recipient $i$, summed from year $t-s$ to year $t-1$; the superscript $m$ denotes one of the three categories of AfT that are broadly related to trade policy, economic infrastructure, and productive capacity; OAfT is the sum of AfT from all donors except country $j ; \delta_{i t}$ and $\mu_{j t}$ capture all time-variant importer and exporter characteristics respectively; $\mathbf{X}$ is a vector that contains both timevariant and -invariant country-pair-specific controls (population weighted distance and dummies for sharing a common official language, for ever being in a colonial relationship, and for whether being in a regional trade agreement) $;^{3} \nu_{i j t}$ is the error term and all other parameters are estimated coefficients.

Our trade data is from CEPII-BACI. All products are defined at 6-digit HS level (1992 version). The AfT data is obtained from OECD Creditor Reporting System (CRS). Following Khandelwal et al. (2013), product-specific elasticities of substitution are taken from Broda et al. (2006) at the median of their multi-country sample. ${ }^{4}$ Bilateral country relationship variables are from Agarwal and Wang (2016) who extend the CEPII Gravity dataset to include more recent years. The period under study is 2002-2010 as complete AfT records are only available after 2002 (Calí and te Velde, 2011). We further restrict our sample to non-OECD exporters and exclude trade with major non-OECD donors (China, India, Saudi Arabia, and Brazil) for which aid data is not available in OECD CRS and the inclusion of these countries would be likely to bias our results.

a great number of varieties to some markets.

${ }^{3}$ Lee et al. (2015) find that WTO members are more likely to receive AfT than non-members. However, we do not include WTO membership dummies for countries or a dyadic dummy indicating the common WTO membership of importing and exporting countries because they would be absorbed by country-year fixed effects here.

${ }^{4}$ The Broda et al. (2006) sample reports country-product-specific elasticities of substitution, but the numbers of countries reported for different products are extremely unbalanced, ranging from 1 to 73 . 


\section{Results}

Following the literature (Calí and te Velde, 2011; Helble et al., 2012; Pettersson and Johansson, 2013), we split AfT into three categories using the broad classification by the OECD. ${ }^{5}$ Our baseline results are presented in Table 1 , where we allow for longer time lags for AfT to have effects on exports than in the above studies. Columns (1)-(5) show that overall AfT in the broadly defined areas of trade policy ("trade policy, regulations, and trade-related adjustment") has the largest positive effect on the quality of exports, and the effect increases when AfT is cumulated over time, implying that the impact takes time to come into full effect. Interestingly, AfT in trade policy from other OECD donors also has a markedly strong and statistically positive impact especially when time lags are taken into account, indicating that some externality may exist between donor and non-donor markets for the quality effect of AfT. Taken as a whole, the average elasticity of quality with respect to AfT is between 0.01 to 0.02 within a five-year window, meaning that a $50 \%$ increase in the value of AfT in trade policy would increase export product quality by $0.5 \%-1 \%$.

[Table 1 inserted here]

Similarly, AfT in economic infrastructure improves the quality of exports, but the effects are statistically less significant. AfT used for building productive capacity, however, has no discernible effect on the quality of exports to the donor, and AfT from the rest of the OECD members may actually lower the quality of exports to a given donor country. While the exact causes of this quality "downgrading" effect requires a closer investigation into the finer content of AfT and the policy transmission channels, ${ }^{6}$ a possible explanation is that AfT in this category may be "tied" to the procurement from the donor and thus compete away resources for exporting high-quality goods to other markets. ${ }^{7}$

\footnotetext{
${ }^{5}$ The classification is accessed via OECD website at: http: //www.oecd.org/dac/aft/Aid-for-trade-sector-codes.pdf.

${ }^{6}$ See Bourguignon and Sundberg (2007) for a general discussion on the possible causes for the mixed effects of AfT found in reduced-form analysis.

${ }^{7}$ See Wagner (2003), Helble et al. (2012), and Pettersson and Johansson (2013), among others, for more detailed discussions on "tied aid" in trade context.
} 
Columns (6)-(10) restrict the export destinations to OECD countries only. Now it emerges that the quality effect of AfT in trade policy gets weaker for recipient-donor trade with the elasticity falling slightly below 0.01, and the effect disappears for AfT from other OECD donors. This finding differs from Columns (1)-(5) and the difference suggests that the cross-market externality of AfT is only limited to non-OECD markets. The fact that other OECD members do not benefit from this spillover probably signals some competition among OECD donors in a manner which is consistent with the abovementioned "tied aid" hypothesis. The effect of AfT in economic infrastructure basically still remains insignificant. AfT in productive capacity now improves quality upto four years down the line but not for other OECD markets, which, when contrasted to Columns (1)-(5), indicates that more productive-capacity-related AfT leads to exports of higherquality products, but this relationship only exists among OECD markets. The negative externality among OECD donors still persists although it is less precisely estimated with a much smaller sample.

To see how AfT changes the recipients' overall positions in the global quality ladder, we compare their predicted positions with AfT against their predicted positions without AfT, taken as mean values in normalized scales, ${ }^{8}$ using the estimated model from Column (5). As shown in Figure 1, it seems that AfT in trade policy and economic infrastructure enable most recipients to upgrade their positions in the global (non-OECD) quality ladder (both by $2 \%$ on average) ${ }^{9}$ while AfT in productive capacity seems much less effective in raising the recipients' quality positions (by $-2 \%$ on average), a finding broadly consistent with Table 1.

[Figure 1 inserted here]

Table 2 examines the intensive and extensive margins of the quality effect of AfT along the market and product dimensions, where AfT is cumulated over the past five years. ${ }^{10}$

\footnotetext{
${ }^{8}$ The normalization is constructed as $\left(\hat{\lambda}_{i j t}-\min \left(\hat{\lambda}_{i j t}\right)\right) /\left(\max \left(\hat{\lambda}_{i j t}\right)-\min \left(\hat{\lambda}_{i j t}\right)\right.$.

${ }^{9}$ Note that the upgrade is less statistically significant for AfT in economic infrastructure judging from the $t$-statistics in Table 1 .

${ }^{10}$ The conclusions we have here are not qualitatively sensitive to the measure of AfT in terms of lagged periods.
} 
Columns (1) and (5) are simply copied from Table 1 for the ease of comparison. As opposed to Column (1) where all market-product observations are included, the sample in Column (4) is trimmed to continued market-product pairs only that appear in all years of the sample period. Columns (2) and (3) focus on one dimension and consist of continued markets and continued products respectively. The comparisons of these columns thus reveal the dynamic sources of the average quality effect of AfT at different margins. Specifically, estimates in Column (4) reflect the most narrowly defined intensive margin, i.e. how AfT affects export quality within existing market-product pairs. The difference between Columns (1) and (2) in sample size reflects the net addition of export markets by any of the AfT recipients, and the equality of sample size between Columns (1) and (3) means no new products were added by any exporters in the whole period.

[Table 2 inserted here]

Although we lose some statistical significance in the continued market sample, totally new markets or products do not affect the quality effect of AfT in trade policy. However, comparing Column (2) against (4), we see that half of the quality effect of AfT in trade policy is due to the addition of higher-quality products in continued markets. A similar pattern is found when contrasting Column (3) to (4), which shows that for continued products AfT encourages the exports of higher-quality varieties to new markets, and this also applies to AfT from other OECD donors. When it comes to AfT in economic infrastructure and productive capacity, most margins do not play a notable role here, although the quality effect spills over more to newly exported markets. The above findings concerning AfT in trade policy are robust to the subsample of OECD markets, while the margins for other categories of AfT now become less prominent. Together, these observations suggest that AfT causes changes in quality mainly through the expansions of the ranges of products and markets in the developing world. 


\section{Conclusions}

We document that aid for trade has some discernible effects on the quality of the recipient countries' exports. In particular, a $50 \%$ increase in the value of AfT received from a donor for assistance in trade policy increases the recipient's export product quality by $0.5 \%-1 \%$ for exports to both donor and other OECD markets. On average, the actual AfT received in trade policy raises the relative position of the recipient country in the quality ladder of all non-OECD countries by $2 \%$. About half of this observed quality upgrading effect is driven by the fact that AfT raises the quality of existing products in existing markets, with the other half coming from higher-quality products being added to the continued markets and higher-quality continued products being exported to new markets. Our research is subject to limitations and can be extended in several ways. For example, our reduced-form results do not reveal any information about the policy making process and transmission channels of AfT; therefore more work needs to be done to open the "black box" of the causality chain (Bourguignon and Sundberg, 2007). It is also worth integrating the current estimation with a global value chain analysis to see how exactly AfT repositions a country' comparative advantage in the global production network.

\section{References}

Agarwal, N. And Z. WAng (2016): "Does the US EXIM Bank Really Promote US Exports," unpublished mimeo.

Anderson, S. P., A. De Palma, And J.-F. Thisse (1988): "The CES and the Logit," Regional Science and Urban Economics, 18(1), 155-164.

(1992): Discrete Choice Theory of Product Differentiation, The MIT press.

Bourguignon, F. And M. Sundberg (2007): "Aid Effectiveness: Opening the Black Box," American Economic Review, 97(2), 316-321.

Broda, C., J. Greenfield, And D. Weinstein (2006): "From Groundnuts to Globalization: A Structural Estimate of Trade and Growth," NBER Working Paper No. 12512.

Calí, M. And D. W. Te Velde (2011): "Does Aid for Trade Really Improve Trade Performance?" World Development, 39(5), 725-740. 
Helble, M., C. L. Mann, And J. S. Wilson (2012): "Aid-for-Trade Facilitation," Review of World Economics, 148(2), 357-376.

Khandelwal, A. (2010): "The Long and Short (of) Quality Ladders," Review of Economic Studies, 77(4), 1450-1476.

Khandelwal, A. K., P. K. Schott, and S.-J. Wei (2013): "Trade Liberalization and Embedded Institutional Reform: Evidence from Chinese Exporters," American Economic Review, 103(6), 2169-2195.

Lammersen, F. And M. Roberts (2015): "Aid for Trade 10 Years on: Keeping It Effective," OECD Development Policy Papers No. 1.

LeE, H.-H., D. Park, And M. Shin (2015): "Do Developing-country WTO Members Receive More Aid for Trade (AfT)?" The World Economy, 38(9), 1462-1485.

NowaK-Lehmann, F., I. Martnez-Zarzoso, D. Herzer, S. Klasen, and A. Cardozo (2013): "Does Foreign Aid Promote Recipient Exports to Donor Countries?" Review of World Economics, 149(3), 505-535.

OECD/WTO (2007): "Aid for Trade at a Glance 2007: 1st Global Review," OECD Publishing, Paris.

(2013): "Aid for Trade at a Glance 2013: Connecting to Value Chains," OECD Publishing, Paris.

Pettersson, J. And L. Johansson (2013): "Aid, Aid for Trade, and bilateral trade: An empirical study," The Journal of International Trade 8 Economic Development, 22(6), 866-894.

Vijil, M. And L. Wagner (2012): "Does Aid for Trade Enhance Export Performance? Investigating the Infrastructure Channel," The World Economy, 35(7), 838-868.

Wagner, D. (2003): "Aid and Trade-An Empirical Study," Journal of the Japanese and International Economies, 17(2), 153-173. 


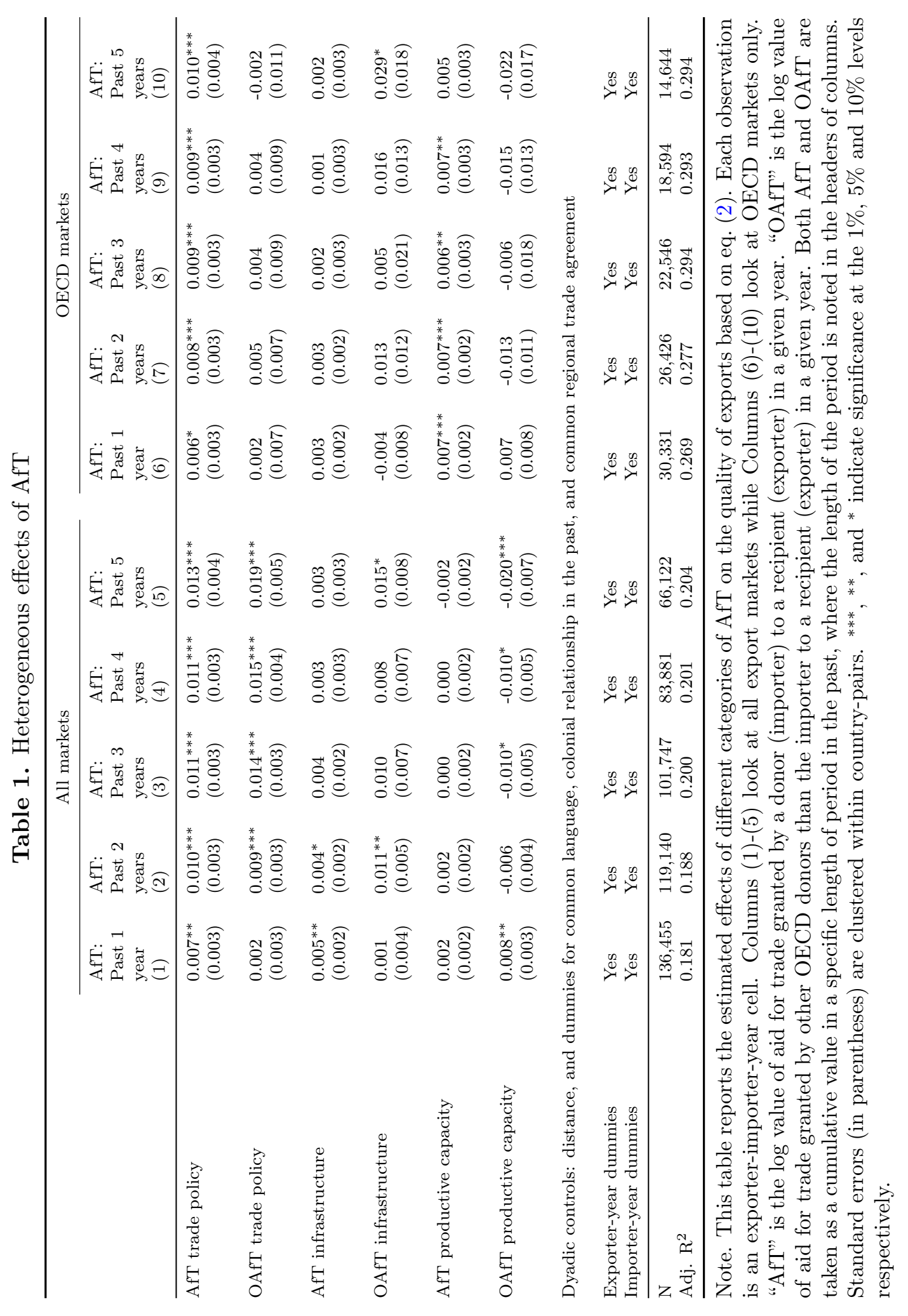




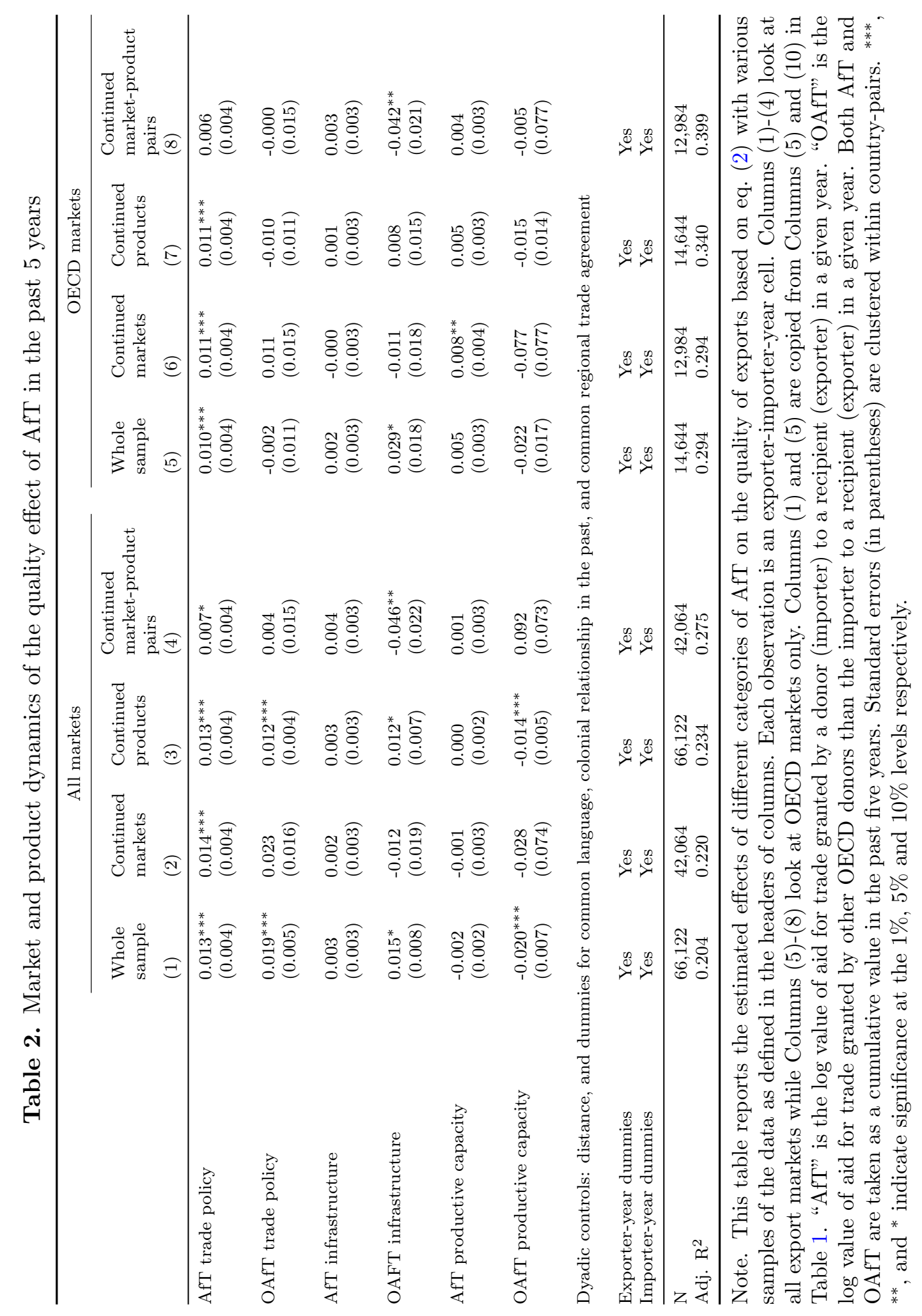



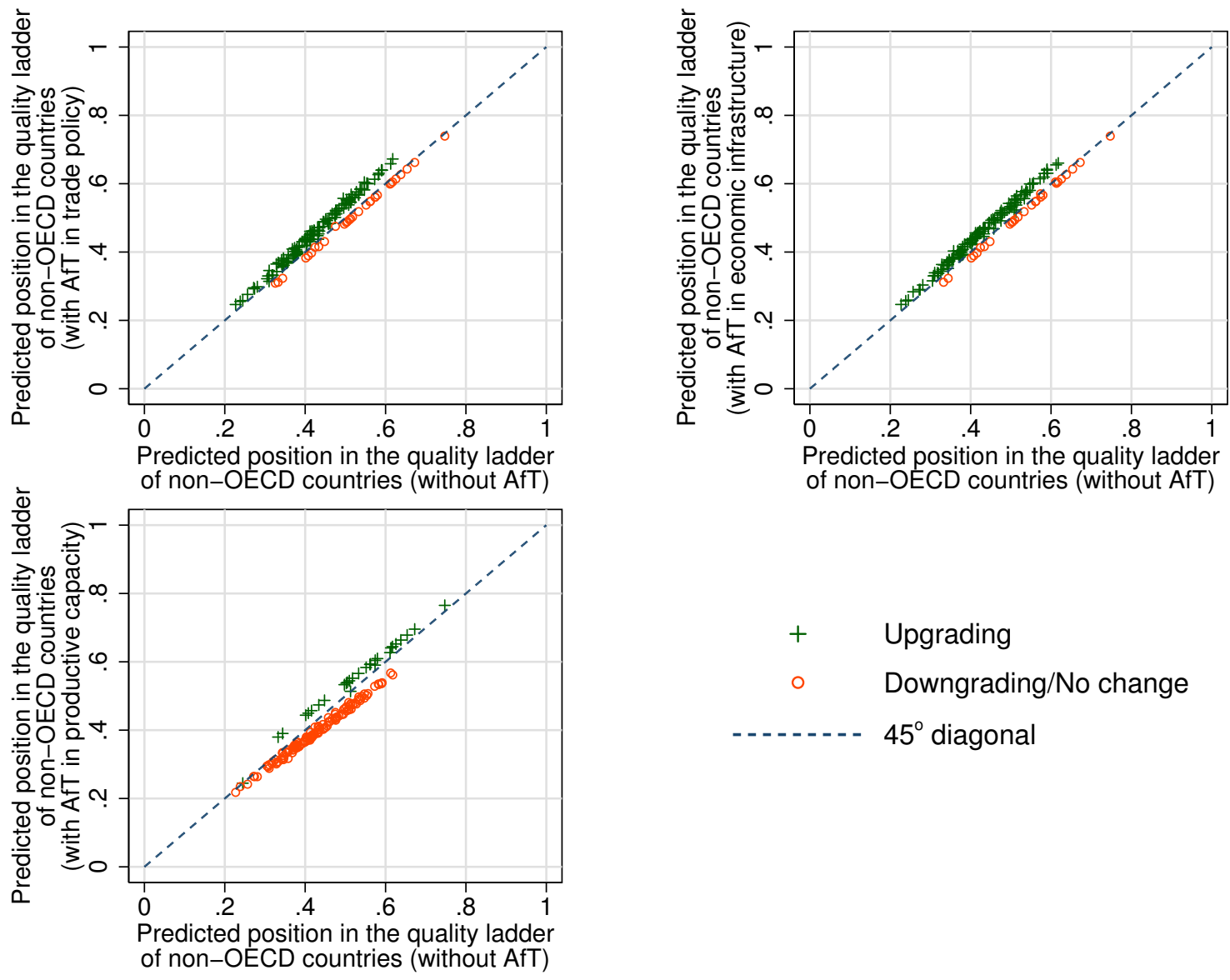

Figure 1. Predicted effects of AfT on recipients' positions in the global (non-OECD countries) quality ladder, 2002-2010. Horizontal and vertical axes are the relative positions of a country in the global quality ladder with and without a specific type of AfT, predicted from the estimated model in Column (5) of Table 1. Each data point represents a non-OECD exporter. The symbols of "+" denote countries whose predicted relative positions, ceteris paribus, upgrade in the ladder because of a specific type of AfT they actually received, and the symbols of "o" denote those whose predicted relative positions, ceteris paribus, downgrade or have no change as a result of a specific type of AfT they were actually granted. The dividing line between quality ladder upgrading and downgrading (and no change) is the $45^{\circ}$ diagonal (dashed line). 